\title{
Conservation Status and Population Density of Himalayan Serow (Capricornis sumatraensis) in Annapurna Conservation Area of Nepal
}

\author{
Achyut Aryal ${ }^{1}$
}

\begin{abstract}
Himalayan Serow 'Capricornis sumatraensis' population is isolated in a small patch of the southern part of Annapurna Conservation Area (ACA) with a population density of 1.17 individual/ $/ \mathrm{km}^{2}$ and a population sex ratio of 1:1.6(Male: Female). A strong correlation was found between population $(y)$ and pellets density $(x)\left(y=0.011 x-0.2619, R^{2}-0.97\right)$. The major problems in the Serow habitat were habitat fragmentation \& land use change, conflict between predator and villager, livestock grazing and poaching. The study was successful in providing information on the present status of Himalayan Serow in the ACA.

अन्नपुर्ण संरक्षण क्षेत्रको दक्षिणी भागमा सानो भुण्डमा $9.9 ७$ प्रति वर्ग कि.मि. जनघनत्व र $9: 9 . ६$ (पुलिड्ग: स्त्रीलिज्ञ) को अनुपातमा छुट्टिएको सानो यसको जनसंख्या एक्लोरुपमा रहेको छ। जनसड्ख्या र वर्कौलाको घनत्वबिच घहिरो सम्बन्ध रहेको पाइयो। हिमालयन सिरोको सरंक्षणका मुख्य समस्याहरुमा वासस्थान टुक्रिनु र जमिनको प्रयोगमा बदलाव, गाउँले विचको दून्द्, गाईवस्तु चरिचरण र गैरकानुनी शिकार हुन्। हिमालयन सिरो संरक्षणका लागि संरक्षण शिक्षा, जनतामाक यसबारे चेतना जगाउने कार्यक्रम आवश्यक देखिएका छन्। यो अध्ययनले अन्नपुर्ण क्षेत्रमा रहेका हिमालयन सिरोको अवस्थावारे जानकारी दिन सफल भएको छ।
\end{abstract}

Key Words: Population density, Sex ratio, Fragmentation, Conservation, Threats

\section{Introduction}

Himalayan Serow 'Capricornis sumatraensis' (hereafter Serow) is a threatened animal, listed in Appendix I by CITES and class as "Vulnerable" by IUCN Red data (IUCN, 2004). It has been given a legal protection in other countries as well (Fox \& Johnsingh, 1997; Green, 1987b; Shackleton, 1997; Wollenhaupt et al, 1997).

Himalayan Serow is locally called "thar" in the study area, belonging to the family Bovidae and subfamily Caprinae. In appearance, the Serow resembles a goral. Serow is a solitary animal (Prater, 1993; Schaller, 1977), although sometimes as many as seven have been seen in a group (Prater, 1993; Nowak \& Paradiso, 1983). It has a large head, thick neck, short limbs, long mule-like ears and a coarse coat of dark hair. It looks like a cross between a cow, a pig, a donkey and a goat. Both sexes are similar in appearance and are about equal size (Schaller, 1977). An adult male Serow measures about 100 to $110 \mathrm{~cm}$ at its shoulders and weighs about $91 \mathrm{~kg}$ on average in its adulthood. Its head and body length measures $140-180 \mathrm{~cm}$. Horns are $15-25 \mathrm{~cm}$ long and $13-15 \mathrm{~cm}$ in girth and are present in both sexes. The horns are black, conical, sharply pointed and directed backwards. Serow has inguinal

${ }^{1}$ Institute of Natural Science, Massey University, New Zealand. Email: achyutsinensis@hotmail.com 
glands and enlarged pre-orbital glands. It inhabits steep, rugged, inaccessible and densely forested areas of the Himalaya. Serow prefers damp and thickly wooded gorges and occurs between 1,500-4,000m (Prater, 1993; Schaller, 1977).

The Serow is oriental in origin (Schaller, 1977). The geographic range is bordered by Jammu and Kashmir (India) in the west to the Japan in the far north-east (Shackleton \& Lovari, 1997; Schaller, 1977). The Mainland Serow is found in China, Myanmar, Thailand, Malaysia, Sumatra, Cambodia, Laos, Vietnam, Bangladesh, India, Bhutan and Nepal (Nowak \& Paradiso, 1983; Prater, 1993; Schaller, 1977; Shackleton \& Lovari, 1997).

The main aim of this study was to determine present status of the Serow in southern belt of Annapurna Conservation Area (ACA) Nepal.

\section{Study Area}

Annapurna Conservation Area, the first conservation area and the largest protected area in Nepal, has adopted a new approach and concept in protected area management. The ACA covers a landmass $7,629 \mathrm{~km}^{2}$ with altitudes ranging from Sub-tropical region to $8,000 \mathrm{~m}$ within a short horizontal distance of less than $35 \mathrm{~km}$. The ACA harbors a recorded total of 1,226 species of plants, 38 species of orchids, 9 species of rhododendrons, 101 species of mammals, 474 species of birds, 39 species of reptiles and 22 species of amphibians (ACAP, 2002).

The study was carried out in the Ghandruk, Landruk and some part of Lwang Ghallel VDCs of Southern Belt of ACA (fig 1). The total study area covered was $206 \mathrm{~km}^{2}$. Due to the combined effect of climatic and topographic variation, this area comprises a wide range of bio-climatic zones, hosting a rich biological diversity. This region exhibits vegetation from sub-tropical forest to alpine grassland. Rhododendron arboreum is the most common species: four species of Rhododendron have been recorded (Poudel, 2003). This region is home to about 48

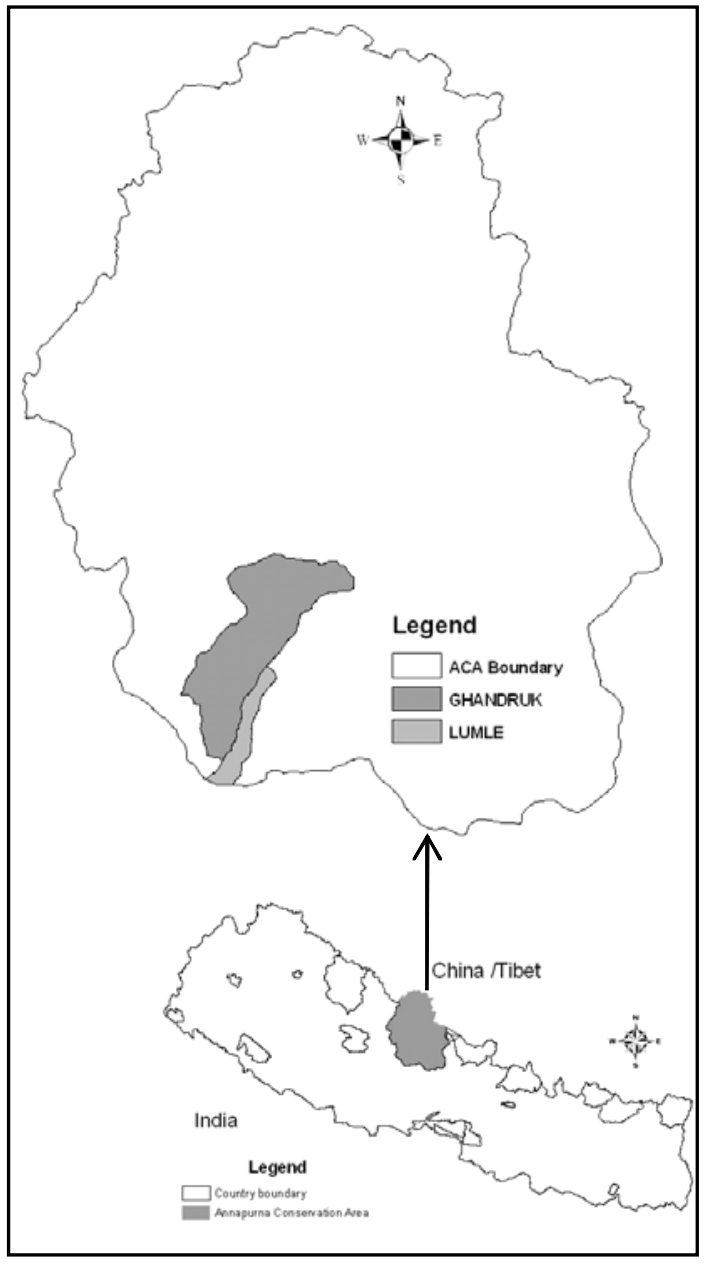

Figure 1: Study area 
mammal species and 210 bird species (ACAP, 2002). Out of five Caprinae species in the country, 3 are present in this area. They are Hemitragus jemlahicus (Himalayan thar), Nemorhaedus goral (Goral) and Capricornis sumatraensis (Serow). Five species of cat including Clouded leopard and Common leopard are found in this region (ACAP, 2002).

\section{Material and methods}

The preliminary survey was carried out to find out potential areas for Serow before the actual field work started. This was done by questionnaires targeted at local concerned and knowledgeable people: villagers, herders, local leaders, and Annapurna Conservation Area staff. Local people were involved with all the aspects of the project on the assumption that they could learn new techniques and share important information with us. The study was carried out in the period January- December 2007.

\section{Silent drive count methods for Serow population count}

Green (1985) was the first to use this density estimation technique for Mammals such as the Serow, Musk deer followed by Kattel (1992); Sathyakumar (1994), Vinod \& Sathyakumar (1999) and Aryal, (2005) Aryal, (2006). The Silent Drive Count is similar to the block drive census method. The study area of potential Serow habitat was divided into small blocks or patches using features such as ridges, streams and foot paths as boundaries. A base line was identified and 8 men were spaced at intervals of $60 \mathrm{~m}$. All these men had some knowledge of the block or patch in which the drive was to be conducted and their line of travel. The men were instructed to scramble quietly through the patch and record ungulates sighted. I and my two research assistants stayed at different vantage points, strategically above the forest level to spot and record Serow. Data on time, species, number and location, with reference to the line of travel and direction of movement of the Serow were recorded. Drives were conducted in early mornings and late afternoons. Duplicate records arising from the same animal being sighted in adjacent blocks or patches were minimized by conducting drives in a direction that flushed the Serow outside the study area rather than towards adjacent blocks or patches. Numbers of Serow were counted in three blocks of study area. Similarly, pellets were counted in Serow habitat in transect $(100 \mathrm{~m} x 1000 \mathrm{~m})$, total 46 transect lines were laid out in the Serow habitat where the population counted in three blocks. In study, transect lines were laid from lower altitude to higher and set 100 meter interval from one transect line to others. In each transect line me with 2 others research assistants walked from lower to higher altitude for searching Serow's pellets. Old and new pellets of Serow were counted and pellet density was calculated with dividing total pellets count by area. The two sets of data (pellets count and population count) were correlated and regression equation was created to predict the Serow population through pellet distribution. Such an equation is appropriate for this ungulate which uses their latrine in the old latrine sites. Telescope and binoculars were used to count from vantage points. 


\section{Results and discussion}

\section{Population status of Serow}

Table 1: Correlation between pellets density and population density of Serow

\begin{tabular}{|l|c|c|c|c|}
\hline \multicolumn{1}{|c|}{ Site } & Male & Female & Juveniles & Total \\
\hline Landruk site & 2 & 3 & & 5 \\
\hline Ghandruk site & 5 & 8 & 2 & 15 \\
\hline
\end{tabular}

Population of Serow (fig 2) was concentrated in area surrounding the Bamboo area where the influence of human population was low. Population survey was carried out in all potential area of Landruk and Ghandruk region on the basis of pellet distribution throughout the area. Total 20 Serow populations were counted through the intensive population survey, which consisted of 7 male, 11 female and 2 juveniles with the sex ratio of male to female as 1:1.6 (Table 1). Green (1987)

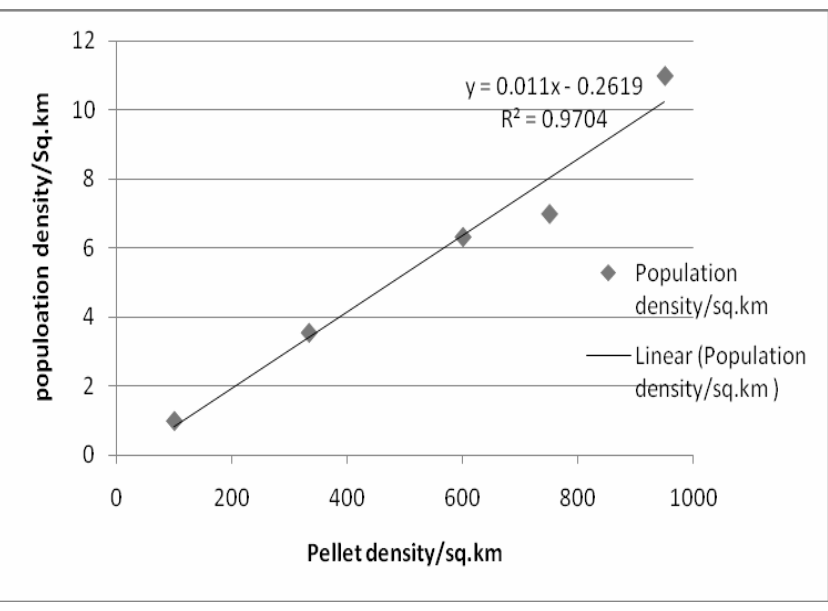

Figure 2: Correlation between pellets density and population density of Serow recorded 1.6 Serow per sq. km within suitable habitat in Kedarnath Sanctuary in India. Green (1987b) has reported a total

Figure 3: Serow at Landruk Forest

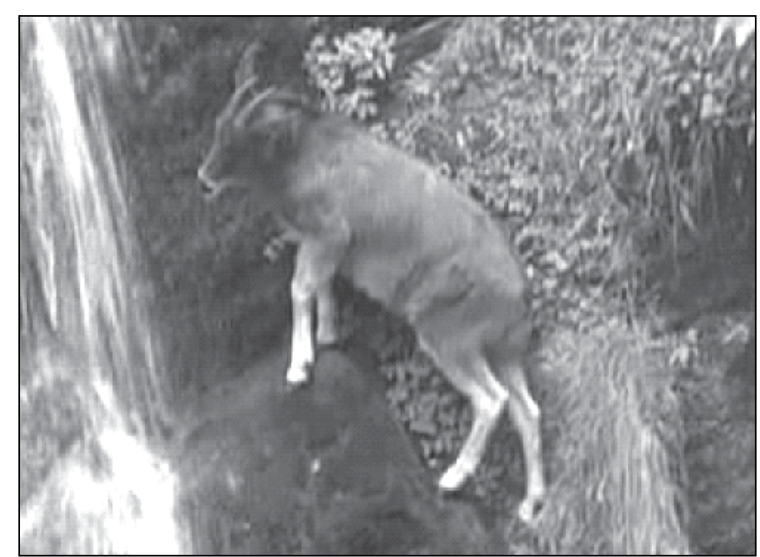

Source: Author, 2008 population of 50-100 Serow occurring in Bangladesh in isolated and scattered units. Present study showed that population density (1.17individual $\left./ \mathrm{km}^{2}\right)$ is slightly lower compared to the Green's 1987 study from India.

Decline of Serow in the study area proceeded at a very rapid pace although ACAP is raising conservation education in local level. On the basis of local elder people's opinion, there was time they could hunt Serow in $500 \mathrm{~m}$ far from the 
Landruk village. But at present, it is very difficult to see Serow as well as other wildlife in their forest; it may be due to over hunting, habitat destruction by human and livestock. Habitat fragmentation in Serow's forest is another threat to population decline.

Fecal dropping behavior of Serow is found unique, it dropped pellets/fecal in old pellets dropping site, so that, it is difficult to use direct methods like pellet count methods in transect line for population estimation. The research tried to develop regression model to predict population through the pellet density so that both pellets and population count survey were carried out in the three blocks of study area. On the basis of this, I developed regression equation $\mathrm{y}=0.011 \mathrm{x}-0.2619$ ( $\mathrm{y}$ - Population density, $\mathrm{x}$ - Pellet density) (Fig.2). The result showed that there is high positive relation $\left(\mathrm{R}^{2}-0.97\right)$ with population density and pellet density. This equation can be used in future for direct monitoring of Himalayan Serow in the area through the pellet survey.

\section{Conservation status of Serow}

Although there is no specific programme in ACAP to conserve Serow in their natural habitat, ACAP has established a Conservation Area Management Committee (CAMC) in Landruk and Ghandruk area for conservation of natural resources. CAMC is directly responsible for monitoring the wildlife of their area, although they have no technical manpower. CAMC patrols their forest regularly. Patrolling activities are facilitated by ACAP authorities who provide some annual funds to CAMC. Ghadruk and Landruk areas are populated by the Gurung people, most of whom are Buddhists. Integrating this cultural perspective into conservation is a key point. Both local hunting and external poaching activities are also threats in the area; poaching is often supported by involvement of local people.

\section{Threats}

\section{- Habitat fragmentation and land use change}

Development of agriculture in the area, local people's high dependence on fuel wood and timber, increase in hotels and trekking routes, increase in settlements area, have played major roles in habitat fragmentation. In the Ghandruk and Landruk site, village, hotel and other infrastructure development are the main causes of fragmenting the forest area in the upper site. This land use change is especially difficult for the Serow as it serves as corridor for Serow and other wildlife movements in Panchase region to Annapurna region. These habitat fragmentations have negative impacts on the continued survival of the Serow and other wildlife species in the area.

\section{- Decline of Serow population and conflict between predator and villagers}

The large population decrease of the Serow and other ungulates from the study area has created changes in the abundance of predator species like Clouded leopards, Common 


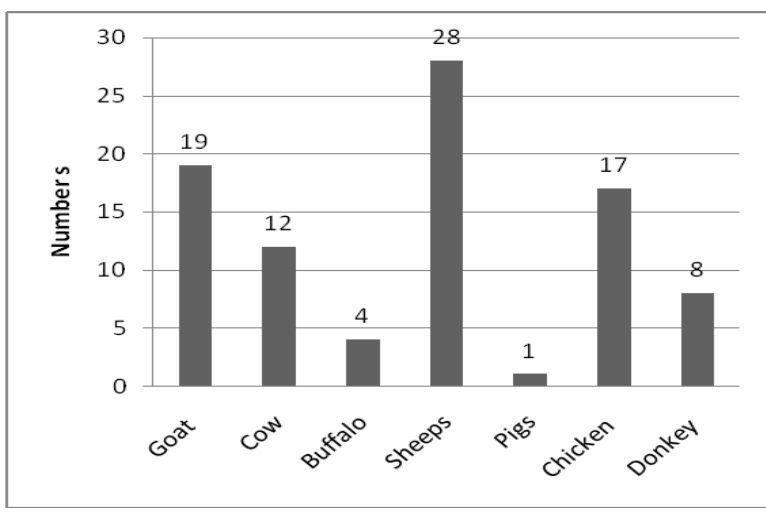

Figure 4: Livestock kills by predators within last 2 years (n-86)

leopard and Black bear. Generally, such predators attack the local livestock only when their natural prey are either depleted or hard to find, so it is one indicator of the declination of the population of Serow and other ungulates from the study area. Due to the loss of such prey species, predators of the study area are starting to use villager livestock as feeding species causing major conflict between the villager and predator species in the study area. Within last two years, 86 livestock animals have been killed by predators in the area which causes further conflicts with the local population (fig.4).

\section{- Livestock grazing in Serow habitat}

Because of high seasonality and low primary productivity, the Himalayan region supports a relatively low ungulate / herbivore biomass (Aryal, 2005). With the increase in the biomass of domestic livestock in many areas, wild ungulates such as Serow have suffered competitive exclusion from some habitats. Most of the study area is under livestock grazing pressure in the Himalaya. In Deurali area, there is less impact by livestock grazing, only $2 \%$ of livestock dung was found in those areas. Others areas have approximately equal influence by the livestock grazing. Resource competition between Serow and livestock is another major threat to the Serow population.

\section{- Poaching of Serow}

Serow poaching is another threat in the study area. Generally, poachers prefer not to hunt Serow - they only use this species if they cannot find others species because Serow meat is less preferred compared with other ungulates. As a result hunting is limited and secretive. We found many snares in study area especially in the Bamboo and Deurali sites where there were a high population of Serow.

\section{Conclusion and Recommendation}

Himalayan Serow 'Capricornis sumatraensis' is a threatened, solitary mammal of Asia. This is first study on this species which was also able to raise conservation education among the local people. The study has collected baseline data on this species and changed local people's attitudes towards the conservation of the Serow in its natural habitat. The research has generated a baseline for further research on this species.

The population of Serow is only concentrated in the southern part of ACA region especially in Ghandruk and Landruk region, therefore the authorities must concentrate more on this 
species for research and conservation. Feeding ecology and its relation with predators should be prioritized for further study to understand its feeding behavior. Co-existing patterns with predators and other ungulates in the area is another necessary area for further research.

The Serow population is isolated in a small patch of the southern part of Annapurna Conservation Area (ACA) with a population density of 1.17 individual $/ \mathrm{km}^{2}$ and a sex ratio of 1:1.6(male: female). A strong correlation was found between population (y) and pellets density $(\mathrm{x})\left(\mathrm{y}=0.011 \mathrm{x}-0.2619, \mathrm{R}^{2}-0.97\right)$. This equation can be used for further monitoring of this species in natural habitats. The present study reflects the small population in the study area, and more study is essential in other areas of Nepal. Information about home range, reproductive behaviors are lacking and inhibits management of this species. Green (1987b) has reported a total population of 50-100 Serows occurring in Bangladesh in isolated and scattered units. The present study showed that population density $\left(1.17\right.$ individual $\left./ \mathrm{km}^{2}\right)$ is slightly lower than Green's 1987 study of India.

Generally, government and researchers alike focus on wildlife like the tiger, rhino, bears, snow leopards etc, that have high economic and illegal market value. These species are easier to raise funds from international sources. This situation causes lack of knowledge about low illegal market value species like Serow, Hispid hare etc. Therefore, concerned agencies (government/NGOs, INGOs, civil society) and researchers must give equal emphasis for in-situ conservation of low illegal market values species such as Serow, which is a prey species for threatened species like leopards.

The major problems in Serow habitats are habitat fragmentation and land use change; reduction of Serow population, conflict between predators and villagers, livestock grazing in Serow habitat, and poaching of Serow. Further research and conservation education are important for conservation of this species.

\section{Acknowledgements}

I would like to acknowledge Professor Dr. Marco Festa-Bianchet (Chair, IUCN Caprinae Specialist Group), Professor Dr. Johann G. Goldammer (Director, Global Fire Monitoring Center, UN-ISDR, Germany), Professor Dr. A.K Das (IOF, Tribhuvan University, Nepal), Professor Dr. I.C. Dutta, Professor, Dr. Ilse Storch and Professor Dr. h. c. Dieter R. Pelz (Faculty of Forest \& Environment Science, Albert- Ludwigs University of Freiburg), Mr. Jill Nelson and Ms. Nida (PTES, UK), Mr. Jose Cole \& Ms. Jane Raymond (Rufford Small Grant Foundation, UK) and Mr. Madhav Prasad Ghimire (Chief Secretary, Government of Nepal), for their remarkable guidance, creative comments and suggestions in all stages of this project. I am highly indebted to People's Trust For Endanger Species (PTES, UK) and Rufford Small Grant Foundation, UK for providing funding for this Project. I would like to acknowledge Lal Prasad Gurung (Project Director, ACAP) for granting me the permission to conduct the project in ACA. Special thanks goes to my colleague Kate for editing and review of the paper. 


\section{Reference}

ACAP, 2002. Annual Report. Annapurna Conservation Area Project.

Aryal, A. 2005. "Status and distribution of Musk Deer 'Moschus chrysogaster' in Annapurna Conservation Area of Manang district" a report submitted to ITNC, UK.

Aryal, A. 2006. "Musk Deer Moschus chrysogaster: Population and conservation status, distribution, habitat structure, poaching in Annapurna Conservation Area (ACA) Kobang VDC of Mustang district of Nepal" a report submitted to British Ecological Society, UK, 2006.

Fox, J. L. \& Johnsingh, A. J. T., 1997. Country report on India. in Shackleton, D. M. (ed) $\&$ the IUCN/SSC Caprinae Specialist Group. Wild Sheep and Goats and their Relatives. Status and Conservation Action Plan for Caprinae. IUCN, Gland, Switzerland and Cambridge, UK 215-231.

Green, M. J. B., 1987b. The conservation status of the leopard, goral and serow in Bangladesh, Bhutan, Northern India and Southern Tibet. Unpublished report by IUCN Conservation Monitoring Center for the United States Fish and Wildlife Services 26p.

Green, M.J.B. 1985. Aspects of the ecology of the Himalayan Musk deer. Ph.D. thesis, University of Cambridge, Cambridge, UK, $280 \mathrm{p}$.

Hall, L. S., Krausman, P. R. and Morrision, M. L. 1997. The habitat concept and a plea for standard terminology. Wildlife Society Bulletin 25:173-182.

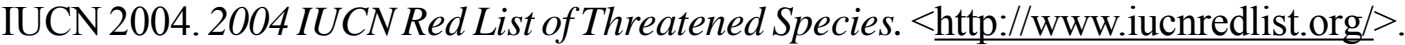
Downloaded on 24 February 2006.

Prater, S. H., 1993. The book of Indian Animals. Bombay Natural History Society, India.

Poudel, B. S., 2003. "An assessment of status of Rhododendron in Ghandruk-Ghorepani region of Annapurna Conservation Area" a research report submitted to Annapurna Conservation Area Project/ KMTNC, Pokhara, Nepal.

Shackleton, D. M. 1997. Country report on China. in Shackleton, D. M. (ed) \& the IUCN/ SSC Caprinae Specialist Group. Wild Sheep and Goats and their Relatives. Status and Conservation Action Plan for Caprinae. IUCN. Gland, Switzerland and Cambridge, UK, 148-172

Schaller, G. B. 1977. Mountain monarchs: wild sheep and goats of the Himalaya. University of Chicago Press, Chicago.

Wegge, P. \& Oli, M.K., 1997. Country report on Nepal. in Shackleton, D. M. (ed) \& the IUCN/SSC Caprinae Specialist Group. Wild Sheep and Goats and their Relatives. Status and Conservation Action Plan for Caprinae. IUCN. Gland, Switzerland and Cambridge, UK. 231-239.

Wollenhaupt, H., Green, M. J. B., Thinley, S. \& Palden, J., 1997. Country report on Bhutan. in Shackleton, D. M. (ed) \& the IUCN/SSC Caprinae Specialist Group. 